UDC 343:98

DOI https://doi.org/10.32850/LB2414-4207.2021.19.21

\title{
TACTICAL ERRORS OF THE ON-SITE RESEARCH DOCUMENTATION STAGE
}

\author{
Ostavciuc Dinu, \\ orcid.org/0000-0001-5317-3296 \\ Doctor of Law, \\ Associate Professor at the Department \\ of Criminal Procedure, Criminology and \\ Information Law \\ (Academy "Stefan cel Mare" of the \\ Ministry of Internal Affairs of the \\ Republic of Moldova, Chisinau, Republic \\ of Moldova) \\ Rusnac Constantin, \\ orcid.org/0000-0002-8122-7711 \\ Doctor of Law, \\ Associate Professor at the Department \\ of Criminal Procedure, Criminology and \\ Information Law \\ (Academy "Stefan cel Mare" of the \\ Ministry of Internal Affairs of the \\ Republic of Moldova, Chisinau, Republic \\ of Moldova)
}

Forensic science has a transformative effect on crime investigation practice by examining its downsides.

One of the tasks of forensic science is the creation of counterbalancing measures to circumstances that contradict the effective development of investigative practice and algorithms aimed at detecting and eliminating errors made in investigative activities.

Errors reduce the quality of the investigation. They can be obvious or hidden. If the mistakes made are not identified, their impact on the investigation is much more serious.

Inspection of the scene is the most important investigative action that is carried out in the investigation of a criminal act. Incompetent investigation at the crime scene, incorrect recording of its results is the cause of serious errors and inadmissibility of evidence that affects the quality and efficiency of the criminal investigation as a whole.

Depending on how well and skillfully this action is performed, the quality and volume of the established information depends, which, in turn, determines the correct choice of means of solving existing problems at the initial stage of the investigation of a criminal case.

The study is intended to identify tactical errors committed during the investigation of the crime scene at the documentation stage by the prosecuting officers of the General Inspectorate of Police of the Ministry of Internal Affairs of the Republic of Moldova. The authors identified the technical and tactical errors in fixing the crime scene, existing in the report of the on-site investigation.

Following the study of the specialized literature and the analysis of the minutes drawn up 
by the criminal investigation officers from different periods of time and regions of the Republic of Moldova, we can state that the following errors are committed at the documentation stage:

1. Wrong drawing up of the report of the investigation of the crime scene

2. Improper packaging of objects and traces picked up during the crime scene investigation.

3. Wrong photography and video recording of the crime scene investigation process

4. Incorrect plotting of the scene of the accident.

The existence of errors in the process of documenting the crime scene investigation is an inevitable phenomenon that will persist being determined by the existence of subjective and objective factors. The errors described are inadmissible in the investigation process, because there is a risk of nullity of the procedural action, or of the inadmissibility of the evidence obtained by this procedure.

Key words: on-site investigation, error, forensic tactics, prosecution, report, sketch, photography.

\title{
ТАКТИЧНІ ПОМИЛКИ, ЩО ДОПУСКАЮТЬСЯ ПІД ЧАС ДОКУМЕНТУВАННЯ ОГЛЯДУ МІСЦЯ ПОДІЇ
}

\author{
Оставчук Дину, \\ orcid.org/0000-0001-5317-3296 \\ доктор права, \\ доцент кафедри кримінального \\ процесу, криміналістики та \\ інформаційного права \\ (Академія «Штефан чел Маре» \\ Міністерства внутрішніх справ \\ Республіки Молдова, Кишинів, \\ Республіка Молдова) \\ Руснак Костянтин, \\ orcid.org/0000-0002-8122-7711 \\ доктор права, \\ доцент кафедри кримінального \\ процесу, криміналістики та \\ інформаційного права \\ (Академія «Штефан чел Маре» \\ Міністерства внутрішніх справ \\ Республіки Молдова, Кишинів, \\ Республіка Молдова)
}

Криміналістика здійснює перетворюючий вплив на практику розслідування злочинів, вивчаючи її негативні сторони.

Одним із завдань криміналістики $є$ створення заходів протидії обставинам, що суперечать ефективному розвитку слідчої практики та алгоритмів, направлених на встановлення та усунення помилок, що допускаються у слідчій діяльності.

Помилки знижують якість розслідування. Вони можуть бути очевидними або прихованими. Якщо допущені помилки не були ідентифіковані, їх вплив на розслідування набагато серйозніший. 
Огляд місця події є однією із найважливіших слідчих дій, яка проводиться при розслідуванні будь-якого злочинного діяння. Некомпетентне проведення розслідування на місці події, неправильна фіксація його результатів стає причиною виникнення серйозних помилок та недопустимості доказів, що впливає на якість та ефективність розслідування кримінальної справи в цілому.

Від того, наскільки якісно та уміло виконано цю процесуальну дію, залежить кількість та обсяг встановленої інформації, що, в свою чергу, обумовлює правильний набір засобів рішення проблем, що виникають на практиці на цьому етапі розслідування.

У досліджені проаналізовані виявлені тактичні помилки, допущені під час огляду місця події співробітниками слідчого відділу Генерального інспекторату поліції Міністерства внутрішніх справ Республіки Молдова, зафіксовані у відповідних протоколах про проведення процесуальної дії.

Вивчивши спеціальну літературу та проаналізувавши протоколи оглядів місця події різних періодів та регіонів Республіки Молдова, складені слідчими, слід констатувати, що на етапі документування допускаються наступні помилки: 1) неправильне складання протоколу огляду місця події; 2) неправильна упаковка предметів та слідів, виявлених під час огляду місця події; 3) неправильне фотографування та відеозапис процесу проведення огляду місця події; 4) неправильне складання схеми місця події.

Наявність помилок під час документування розслідування на місці події - це неминуче явище, яке зберігатиметься й визначається наявністю суб'єктивних та об'єктивних факторів. Описані помилки недопустимі під час розслідування, адже існує ризик недійсності процесуальної дії або недопустимості доказів, отриманих за допомогою таких методів.

Ключові слова: розслідування на місці події, тактико-криміналістична помилка, обвинувачення, протокол огляду місця події, схеми, фотографії.

Introduction. The investigation of the place is the most important and frequent criminal prosecution action that is carried out within the investigation of a criminal act. Incompetent conduct of the investigation of the crime scene, incorrect recording of its results are the reasons for the occurrence of serious errors and inadmissibility of evidence that affect the quality and effectiveness of criminal prosecution as a whole.

According to how efficiently and skillfully this action is carried out, depends de quality and volume of the established information, which, in turn, determines the correct choice of the means of solving the existing problems at the initial stage of the investigation of the criminal case [54, p. 4].

Purpose of the study. This article aims to identify forensic errors committed in carrying out the crime scene investigation at the documentation stage.

Methods applied and materials used. In the process of elaborating the scientific article, the authors were guided by a system of scientific research methods, and namely: grammatical method, systemic method, method of deduction and induction, method of analysis, comparative method and many others. The theoretical-legal basis of the scientific article includes the normative regulations regarding the investigation of the crime scene, the procedural-criminal and criminological doctrine in the field of the investigation of the crime scene. Also, in the process of elaborating this study, the practice of law enforcement bodies was taken into account, studying and analyzing in this sense an impressive number of on-site investigation reports in criminal cases in which the criminal investigation was suspended.

Results obtained and discussions. Speaking about the forensic errors of the crime scene investigation, we are aware that they can be committed at any stage of the investigation, but the errors of the documentation stage have a vital significance. 
Base on the legal provisions, we can mention that the fixing of the research results on the spot takes place by the following means: on-site research report, sketch of the crime scene, photography, judicial phonogram and video-phonogram [53, p. 32].

According to the study of the specialized literature and the analysis of the minutes drawn up by the criminal investigation officers from different periods of time and regions of the Republic of Moldova, we can say that the following errors are committed at the documentation stage:

1. Wrong elaboration of the on-site investigation report

Wrong elaboration of the on-site investigation report is a current problem. The report of the crime scene should reflect the course and results of this investigation and serve as evidence. Referring to the importance of the on-site research report Ivan Iakimov wrote: "It is not enough to observe and discover what is important and necessary for the case during the research. This is only half of the task, the other is to capture and consolidate everything that was observed and discovered during the examination" [57, p. 30].

In our opinion, the following errors are admitted in the report of on-site investigation:

a) the objects and traces discovered are not described completely, objectively and multilaterally. Thus, in $87 \%$ of cases the shape, size, color, construction features, natural destination and concrete destination of objects and traces are not described. Likewise, the shape, color, dimensions, condition of the trace object are not described;

b) the subjective assessments of the criminal investigation officer. In the process of investigating the crime scene, it is unacceptable to set the subjective assessments of the criminal investigation officer or the specialist (forensic officer, medical examiner) about the time and method of the offense, the offender's actions on the spot, the consequences of the offense, the presence of the causal link between the offender's actions and the resulting consequences, and other circumstances. However in $85.7 \%$ of cases such errors are allowed;

c) recording the conclusions and versions. It should be recalled that during recording the results of the on-site investigation it is not allowed to draw conclusions and elaborate versions of the circumstances of the act. Regarding the respective error, we find that in $85.7 \%$ of cases the report contains such phrases as: "traces of blood", "gold earrings", "traces of the offender", "place of the crime", "place where the goods were stolen". There are cases in which the criminal investigation officer (sometimes on the advice of the specialist) concludes that the traces discovered are invalid for identification of the object creating the trace and based on this does not remove the traces from the crime scene. This approach is absolutely unacceptable. Firstly, the formulation of the findings during the investigation of the crime scene contradicts the essence and tasks of this criminal investigation. Secondly, the impossibility of performing a traditional examination for identification purposes (for example, dactyloscopic expertise) does not exclude the use of traces in other types of modern expertise (cretoscopy and poroscopy expertise). In addition, traces can be examined to determine the mechanism of formation. The need for such an investigation is not always obvious during the investigation of the crime scene; therefore, the refusal to remove the traces seems unjustified. In the same context, we mention that the criminal officers, and in some cases the criminal investigation officer, use at the crime scene the traditional method of detecting digital traces - the physical method (use of magnetic and non-magnetic powders). This method excludes the possibility of examining traces detected by the use of modern special knowledge, for example poroscopy. This is due to the fact that many prosecuting officers do not have enough information about the modern possibilities of forensic expertise, and some specialists unwilling to do additional work deliberately mislead the prosecuting officer that modern examinations are very complicated and expensive; 
d) expressions and terms that are not unanimously accepted are used. In 30\% of cases, criminal investigation officers use in the on-site report such phrases as: it seems to be "it seems to be blood", almost "almost empty", regionalisms and special terms not understood for participants;

e) similar objects are designated by different terms, for example: room is identified as chamber, place. We identify this error in $10.2 \%$ of cases;

f) recording the fable of the crime, the statements of the victim, witnesses, etc. This is prohibited, except for the objections of the participants in the trial. However, the statements are to be specified in the minutes of the hearing. However, in $8.5 \%$ of cases the report of on-site investigation contains the respective error.

Reiterating the issue of recording the statements of the witness, the victim, etc., in the report of the investigation of the crime scene, we mention that some authors do not consider this fact as an error and provide a model of the investigation report of the crime scene in which the statements of the witness are included";

g) the same investigated object in the content of the report is named differently in $6 \%$ of cases, for example: window leaf, glass, window or slot;

h) the description of the object does not flow from the general to the particular, but conversely, the individual and then the general signals are described, which contradicts the tactical recommendations for describing the traces and objects discovered at the crime scene. We find this error in $35.6 \%$ of cases;

i) erroneous use of prepositions for the criminal investigation action. In $67.3 \%$ of cases the on-site investigation report contains such propositions as: "near", "not far", "thereby", which render the position of the object or trace discovered in relation to a fixed landmark. The use of these phrases makes it impossible to subsequently reconstruct the deed and the criminal investigation experiment, with the same positioning of the objects existing at the time of the investigation. In the same context, some minutes of the investigation of the crime scene include as landmarks moving objects, which is inadmissible for this procedural action. In our opinion, it is possible that a movable object (for example: chair, table, etc.) represents a landmark, only if it was fixed in the researched space by means of two fixed landmarks;

j) Objects and traces positioning only according to a single immovable landmark. This error refers to the positioning of objects and traces discovered in the criminal field and is committed in $95 \%$ of cases. We consider that there must be at least two immovable landmarks, and in some cases, for example, in the case of corpse positioning, at least three. The need for at least two landmarks is imposed by the fact that if the positioning of the discovered object or trace is based on only one landmark, there is a probability that the object or trace will not be positioned correctly during the reconstruction of the act and the prosecution experiment (see the figure 1-3).

\footnotetext{
${ }^{1}$ "At the scale of the block, at the indicated address, the operative group was greeted by Taras Olealin, domiciled in Chişinău, Columna Street, No. 115/2, ap. 50, phone 24-16-12, who announced that he is the uncle of the victim Olealin Nicolai, aged 21, student at the Department of Foreign Languages of the Free International University from Moldova, and that he found the nephew's body in the apartment at 13.50, urgently announcing the police. Olealin Taras stated that he did not move the corpse, did not move the position of the surrounding objects and did not allow access to any person to that place. Further, the on-site investigation was carried out in the presence of Olealin Taras"https://cj.md/wp-content/uploads/2019/01/Modele-de-acte-procedurale-penale-Volulmul-I.pdf
} 


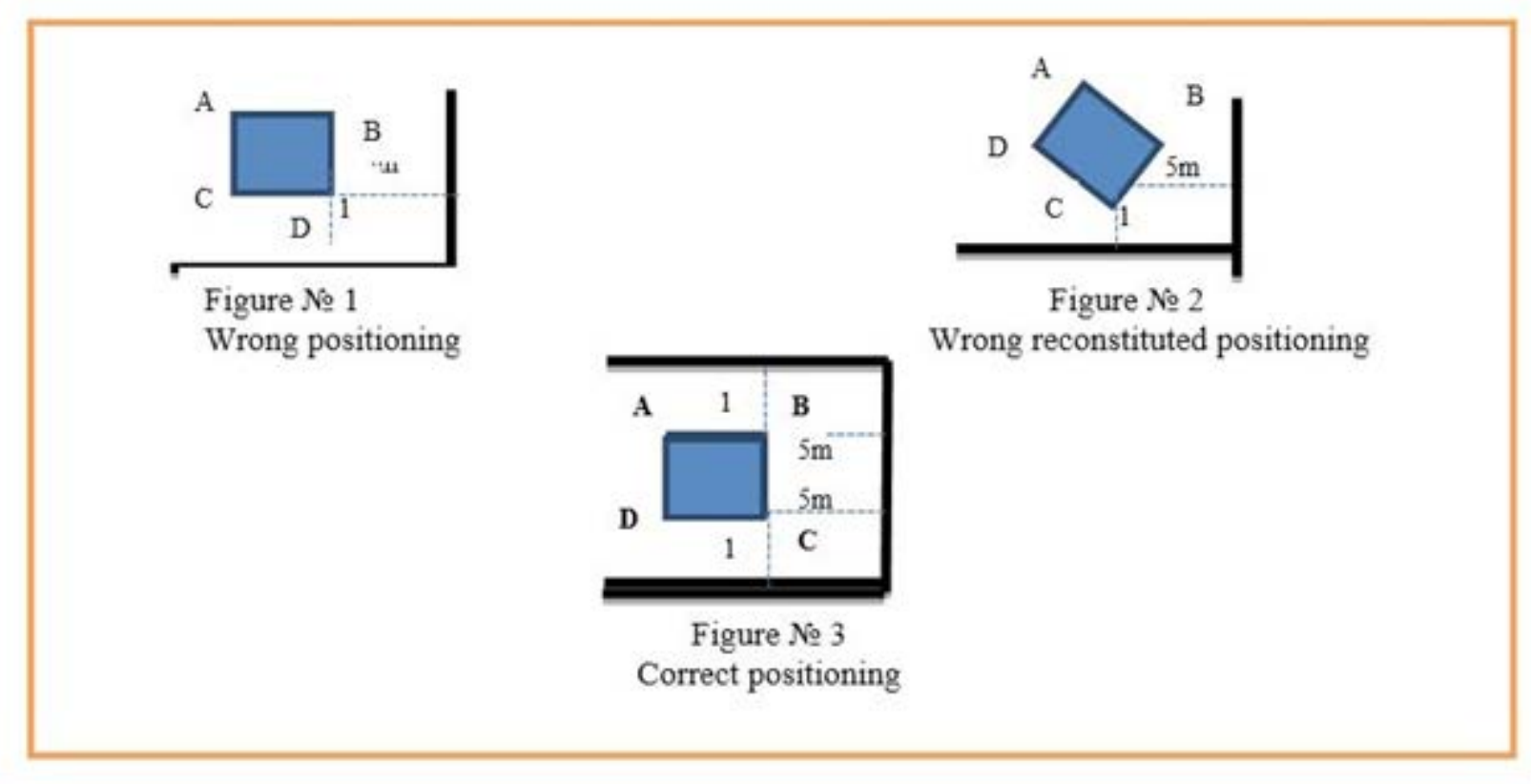

Figure 1-3.

With regard to the correct spatial positioning of the object, it is important to point out that criminal prosecutors and forensic officers use measuring instruments, the accuracy of which is not supported by the necessary documents.

It is important not only to use certifying measuring instruments, but also to determine correctly the reference points from which the measurements are made. It is necessary for such landmarks to be not only motionless, but also to represent a point (not a line, not a circle or other figure), in addition, these objects must be identified individually by indicating the general and individual signs. In particular, trees should not be used as landmarks unless they are single or have no individualizing signs, temporary structures that can be dismantled, etc. If the necessary landmarks are not available on site, it is recommended to use artificial landmarks, called "beacons" which will allow you to accurately record the location of traces and objects important to the case. Objects (poles, bottles with notes, etc.) that cannot be easily destroyed by random people should be used as "beacons".

It is recommended that all measurements should be made in a single unit of measurement (the unit of measurement is chosen by the prosecuting officer who draws up the report according to the circumstances, the surroundings of the crime scene and the traces, objects found, for example: $\mathrm{m}$, $\mathrm{cm}$ or $\mathrm{mm}$ );

k) Incomplete description of all the circumstances and surroundings existing at the crime scene, which leads to the impossibility of further reconstruction of this environment (for example, there is no any indication of climatic conditions, the existence of the nearby constructions, the lack of light pylons, etc., which makes it difficult to carry out, later the reconstruction and the procedural experiment). Unfortunately, we find this error in $91.8 \%$ of cases;

1) erroneous description of unknown objects. In $37.6 \%$ of cases, during the investigation of the crime scene, the criminal investigation officer discovers objects that are known to him in appearance and in the process of identifying and examining them erroneously describes them, for example: handmade firearm is identified as firearm. In our opinion, the only correct solution in cases when the criminal investigation body is faced with the problem of describing unknown objects is the refusal to use the terms denoting them. Instead, it is advisable to use broader concepts, the application of which is not in doubt, with a detailed indication of those features established by direct perception, which exclude any subjective judgement. If 
it is not known which object was discovered during the investigation of the crime scene, it is advisable to use the broadest concepts regarding the object. For example, it was discovered "...an object in the form of a parallelepiped with dimensions of $76 \times 52 \times 12 \mathrm{~mm}$, of plastic, of black color...";

$\mathrm{m})$ the research report is drawn up in a negligent form, some entries are impossible to be read. This error is identified in $24.4 \%$ of cases. We consider that in such situations the parties participating at the crime scene or those who will later become aware of the respective procedural action may intervene with the criminal investigation officer in order to decipher the aspects and circumstances indicated in the minutes.

n) the existence of spelling and grammatical errors. The person conducting the on-site investigation, in $9.6 \%$ of cases, commits spelling and grammar errors which in some cases affect the textual content of the minutes of the action. Likewise, many corrections are made that are not agreed with the persons participating in the on-site investigation;

o) use of abbreviations. In $12.2 \%$ of cases the person conducting the on-site investigation in the minutes of the action uses abbreviations (for example: $s / t-$ are, $p / u-$ for, e/e - is, etc.), without elaborating a legend in this regard. This is unacceptable both from the point of view of forensic science and from a procedural point of view;

p) the descriptive part of the investigation report of the crime scene contains free spaces. In $14.2 \%$ of cases, the person conducting the on-site investigation in the minutes of the action in an inadmissible way leaves a vacant space, because subsequently, those spaces may be filled in with erroneous data or which do not correspond to the factual data at the time of the investigation;

q) the technical-scientific means used in the investigation of the crime scene are not indicated or are incompletely indicated, for example: in some cases it is not indicated the types of dust used to detect traces, in others it is not indicated the type of camera used, the memory card, the use of the brush, ruler, protractor, etc. We find this error in $75.5 \%$ of cases.

$\mathrm{r})$ it is not indicated the way of sealing and packing the traces and objects discovered during the investigation of the crime scene. The error persists in $65.3 \%$ of cases.

The above errors identified as a result of the analysis of the minutes drawn up by the criminal investigation officers from different time periods and regions of the Republic of Moldova do not represent an exhaustive list, there are other errors found during our own experience;

s) incorrect fixing of the time of completion of the action. The person conducting the on-site investigation shall determine the time of completion of the action, the time at which the examination of the crime scene or the examination of the objects is completed;

$\mathrm{t})$ the presence of specialists necessary for a complete and objective research is not ensured;

$\mathrm{u}$ ) in case when the investigation of the crime scene is interrupted, the minutes of the action do not contain inscriptions regarding the time of the interruption and resumption of the action, the reason for the interruption of the data regarding the fact that the causes that determined the interruption have been removed. In the same context, we mention that the investigation of the crime scene after the interruption is recommended to be resumed by the same operative investigation group, in particular a criminal investigation officer, in order to ensure the continuity of the action;

v) In cases when the investigation of the crime scene has been interrupted, no measures are taken to protect and guard the crime scene, such as: sealing of the crime scene, appointment of persons who will ensure the integrity and security of the crime scene, etc.

\section{Improper packaging of objects and traces removed during the investigation of the crime scene.}

a) removed objects, traces are not properly sealed. In $65.3 \%$ of cases there are no explanatory notes on the packaging regarding what was picked up, where it was picked up, the number 
of the traces and objects picked up, name, surname, position of the person responsible for packaging and sealing, etc.;

b) the material traces are all packed together. By packing the traces and objects in a common package, there is a risk of changing their general and individual indices during transportation, and if they are packed one by one, the fixing inside the package is omitted, which leads to the loss of information;

c) incorrect collection of traces (or the trace object), for example, traces of odor are wrapped in paper, not in glass jars with metal lids or silver foil, objects bearing traces of odor are processed with dactyloscopic powder.

\section{Wrong photography and video recording of the crime scene investigation process}

Photography is taken, in some cases, after the crime scene has been changed. As a rule, the photo is taken by a specialist (forensic officer) who photographs only what he considers necessary without paying attention to what may be important for the investigation of the criminal case. Speaking about the operative judicial photography at the crime scene, it should be emphasized that the criminal officers, execute the judicial photography of the crime scene without respecting the technical and methodical recommendations regarding the genres and procedures, and operative photographic plates are not a cluster of logically structured images highlighting the crime scene with all the main objects and individual clues, but are sequential images that are not logically positioned without being characterized and that raise many question marks, although it should be vice versa.

Researching the subject of video fixing of the crime scene, we mention the opinion of the author Semtov V. that the use of video recording technique is of great importance for the rapid discovery of the crime. If the prosecuting officer has a video camera, he has the possibility to repeatedly reconstruct the recordings for the purpose of analyzing the investigations carried out and studying in detail the results obtained [56].

The importance of video recordings made during the crime scene research was also investigated by local authors Odagiu Iu., Luchin L., Rusnac C. who mention that the video recording made during the crime scene investigation offers the possibility to print and reproduce the image with great accuracy and the sound of criminal activities; of some phenomena, circumstances and states of fact in the static phase and especially in the dynamic one; of the appearance of objects, as it appears to our sight; details, shades of color and micro-phenomena of objects under research, which are inaccessible to ordinary view [52, p. 42].

In the situation when the judicial video is applied to the crime scene, the technical process of fixing the crime scene investigation guarantees the following errors:

a. the full presentation of all members of the research operative group is not made before the chamber;

b. the moment of explaining the rights and obligations of the participants is not registered;

c. the name of the institution within which the video recording is made is not fixed;

d. the person making the comment is not appointed;

e. characteristics of the video technique through which the video recording is made and on which the recordings will be stored are not described;

$\mathrm{f}$. the time for starting and completing the action is not fixed, likewise, in cases when the investigation of the crime scene is interrupted, the reason for the interruption is not fixed;

g. not all genres and procedures of the judicial video-film are accomplished;

$h$. no comments are made on the traces discovered and the actions that resulted in the discovery of traces or objects that are important for the criminal case. 
i. often the video recording is made without the soundtrack, thus losing the possibility of fixing the existing sound at the crime scene;

j. it is not fixed the reading by the participants of the minutes of the on-site investigation, as well as, the existence or non-existence of completions, objections from the participants in the action, etc., are not fixed in the video.

\section{Wrong elaboration of the sketch of the crime scene}

The outline of the crime scene is not drawn up in cases when its existence is vital or if it is drawn up contains many ambiguities and errors of content. Likewise, confusion is created between the sketch drawing and the sketch plan. It is also limited to drawing up a type of sketch, for example, a horizontal projection sketch while avoiding the folding sketch and it is also lost sight the fact that the prosecuting officer should not limit himself to drawing up a single sketch, but may draw many types:

1) orientation sketch - includes the crime scene with the environment;

2) sketch of a portion - covers the whole place of the deed, provides information on the relationship between the traces;

3) sketch of the main objects - covers the most important sector of the crime scene;

4) sketch of traces and details - certain traces and details are fixed separately.

The following rules are neglected when drawing up the sketch:

1) accuracy of the sketch - the measures must be executed correctly and the results must be retained and used in the sketch exactly, because each dimension influences the others and any mistake affects the exact wording of the situation;

2) sketch rating - it is necessary to have some kind of dimensioning on the sketch, in order to use the same unit of measure;

3) orientation of the sketch - the sketch must be oriented according to cardinal points. The north is indicated by an arrow, and the south, east and west are determined by the position of the north;

4) clarity of the sketch - the sketch must contain an absolutely essential element necessary for understanding of the existing situation in the field;

5) representation by conventional forensic signs - in order for a sketch to be read easily, it is necessary to use conventional signs when drawing it up. The rendering of some objects, details or elements for which no conventional forensic signs are provided is made by standardized conventional topographic signs, figures or by those used in other fields of activity;

6. Individualization of the sketch - the sketch must be individualized by mentioning the following: the title, scale, date, place, etc.

During the elaboration of the sketch of the crime scene, the existence of several supplies is lost of sight.

1. title, where should be indicated:

a. the sketch is on scale (plan-sketch) or simple (drawing-sketch);

b. what is represented in the sketch;

c. the place of discovery of the object, represented in the sketch;

d. on the basis of what criminal investigation action and in the framework of what criminal case the sketch was drawn up;

e. date, month, year of preparation;

2. scale, if it was used;

3. orientation of the image in the sketch to be made in connection with the "North-South" directions;

4. enumeration of the objects and traces indicated in the sketch and their correspondence with those fixed in the on-site research report;

5. existence of the legend; 
6. the signature of the prosecuting officer and of the other participants;

Conclusions. In conclusion, we could mention that the list of errors stated above is not exhaustive and depending on the type of crime scene investigation, the type of crime committed, their list may be enlarged. The existence of errors in the process of documentation of the crime scene investigation is an inevitable phenomenon that will persist being determined by the existence of subjective and objective factors. The errors described are inadmissible in the investigation process, because there is a risk of nullity of the procedural action, or of the inadmissibility of the evidence obtained by this procedure.

1. Criminal case No. 2020440156

\section{References:}

2. Criminal case No. 2020440152

3. Criminal case No. 2020440124

4. Criminal case No. 2020440150

5. Criminal case No. 2020440443

6. Criminal case No. 2020440146

7. Criminal case No. 2020440344

8. Criminal case No. 2020440189

9. Criminal case No. 2020440199

10. Criminal case No. 2020440292

11. Criminal case No. 2020440114

12. Criminal case No. 2020440061

13. Criminal case No. 2020440207

14. Criminal case No. 2020440301

15. Criminal case No. 2020440052

16. Criminal case No. 2020440048

17. Criminal case No. 2020440232

18. Criminal case No. 2020440244

19. Criminal case No. 2020440107

20. Criminal case No. 2018421745

21. Criminal case No. 2018421611

22. Criminal case No. 2018421336

23. Criminal case No. 2018421723

24. Criminal case No. 2018421633

25. Criminal case No. 2020421969

26. Criminal case No. 2020421499

27. Criminal case No. 2020421942

28. Criminal case No. 2018421681

29. Criminal case No. 2019481076

30. Criminal case No. 2019481082

31. Criminal case No. 2019481074

32. Criminal case No. 2019480665

33. Criminal case No. 2020480174

34. Criminal case No. 2020480168

35. Criminal case No. 2020480163

36. Criminal case No. 2018480583

37. Criminal case No. 2018480595

38. Criminal case No. 2018480591

39. Criminal case No. 2020030688

40. Criminal case No. 2020030464 
41. Criminal case No. 2020030406

42. Criminal case No. 2020030114

43. Criminal case No. 2014031045

44. Criminal case No. 2014031011

45. Criminal case No. 2014031127

46. Criminal case No. 2019030111

47. Criminal case No. 2019030119

48. Criminal case No. 2019030451.

49. Codul de procedură penală al Republicii Moldova: nr. 122-XV din 14 martie 2003. În: Monitorul Oficial al Republicii Moldova, 2013, nr. 248-251.

50. Didac V s.a. Modele de acte procedurale Volumul I. Chisinău, 2007, p. 27 https:/ / cj.md/wp-content/uploads/2019/01/Modele-de-acte-procedurale-penaleVolulmul-I.pdf (vizitat 15.10.2020)

51. Dolea I. Drept procesual penal. Chisinău: Cartier Juridic, 2005.

52. Odagiu Iu., ş.a. Cercetarea la fața locului. Ghid practic. Chişinău: S.n., 2013.

53. Ostavciuc D., Odagiu Iu. Tactica efectuării cercetării la fata locului. Ghid metodic pentru ofiterii de urmărire penală. Chisinău: Cartea Militară, 2020.

54. Потапова Н. Особенности осмотра места происшествия по делам о преступных нарушениях правил охраны труда на предприятиях. Российский следователь. 2010. № 2 .

55. Процессуальные ошибки на стадии предварительного расследования и путь их устранения. https://scienceproblems.ru/protsessualnye-oshibki/3.html (vizitat 15.10.2020).

56. Семенцов В.А. Видео и звукозапись в доказательственной деятельности следователя. Москва, 1997.

57. Якимов Н.И. Криминалистика. Руководство по уголовной технике и тактике. M.: 2001. С. 194. In: Латыпова М.Г. Актуальные проблемы при осмотре места происшествия. Вестник Уфимского юридического института МВД России. 2013. № 2. 